\title{
International student teachers as intercultural experts?
}

\author{
Hahl, Kaisa
}

Routledge

2020-04-16

Hahl , K \& Koirikivi , P 2020 , International student teachers as intercultural experts? in F Dervin , R Moloney \& A Simpson (eds), Intercultural Competence in the Work of Teachers :

Confronting Ideologies and Practices . Routledge , Abingdon, Oxon , pp. 175-196 . https://doi.org/10.4324/97804294

http://hdl.handle.net/10138/314444

https://doi.org/10.4324/9780429401022-14

acceptedVersion

Downloaded from Helda, University of Helsinki institutional repository.

This is an electronic reprint of the original article.

This reprint may differ from the original in pagination and typographic detail.

Please cite the original version. 


\title{
International student teachers as intercultural experts?
}

\author{
Kaisa Hahl \& Pia-Maria Koirikivi \\ Faculty of Educational Sciences, University of Helsinki, Finland
}

\begin{abstract}
Schools have become more diverse in recent years and thus the issue of accepting and dealing with diversities has become increasingly topical. The ways in which cultures and identities are perceived and how representations of these are transmitted in education are central questions for all educators. Multicultural education is part of teacher education but little is yet known whether student teachers are adopting critical perspectives to multiculturalism that they can apply in schools. This study looks into the notions of culture and diversity as perceived by student teachers in an international teacher education program in Finland. The authors analyzed language and science student teachers' focus group discussions in order to investigate what (kind of) intercultural competences they expressed and how they approached questions of culture and diversity as part of their professional expertise. The findings suggest that although many student teachers were aware of the fluidity of cultures and identities, traditional stereotypical images were yet present in their discussions. The student teachers regarded themselves international but yet often considered themselves as cultural representatives of the countries they are from. Nevertheless, many of them were aware of the dangers of categorization and simplification of identities and cultures.
\end{abstract}

Keywords: culture, cultural, intercultural competences, international teacher education, student teachers

\section{Introduction}

Education should give pupils an understanding of the surroundings one lives in and provide tools for critical reflection and understanding of others (e.g. Sobre, 2017; Hernández-Bravo, Cardona-Moltób, \& Hernández-Bravo, 2017). According to the aims of intercultural education, this can be done by taking the diversity of pupils' linguistic, religious, and other backgrounds into account in teaching and by supporting pupils' engagement in the local community and global world (Davis, Phyak, \& Bui, 2012). The concept of culture is used in critical intercultural studies to describe a combination of various sets of values, worldviews, and habits that change over time (Dervin, 2011). Like all social identities, cultural identities are created in certain contexts and they can have a strong impact on people's lives (Davis, Phyak, \& Bui, 2012). Furthermore, these identities are also "fluid" (Bradatan, Popan, \& Melton, 2010, p. 176) by nature and uniquely perceived by each individual (Dervin, Paatela-Nieminen, Kuoppala, \& Riitaoja, 2012).

Following the ideas presented in international literature regarding intercultural education (e.g. Davis, Phyak, \& Bui 2012; Malazonia, Maglakelidze, Chiabrishvili, \& Chiabrishvili, 2017), the new Finnish National Core Curriculum for Basic Education 2014 (FNBE, 2016) emphasizes that teaching and learning activities should enhance all pupils' engagement to local communities, improve their abilities to work with people from different countries and backgrounds, and to foster interest toward different cultures. These new starting points of the curriculum provide vast freedom for the schools and teachers. However, they also challenge teachers as no clearly defined guidelines exist for carrying out intercultural education. Similar situations and challenges are also recognized by many other countries (e.g. Hernández-Bravo, Cardona-Moltób, \& Hernández-Bravo, 2017; Malazonia et al. 
2017). Likewise, there has been much discussion about the ways that teacher education programs should prepare student teachers to recognize and reflect on questions of cultural plurality (Holm \& Londen, 2010). Otherwise teaching staff may even reinforce cultural stereotypes and perceive the children as stereotypical representatives of a certain culture, and thus neglect the individuality of the pupil (Sobre, 2017).

Despite the large number of studies about the importance of intercultural competences, notably less attention has been given to the development of these competences in teacher education programs and particularly in relation to subject teacher education (subject teachers or specialists who teach at the secondary school levels) (Zembylas \& Papamichael, 2017). In order to contribute toward filling this gap in research, this study investigates how international student teachers studying in a subject teacher education program conceptualize cultural diversity and intercultural competences as part of their professional expertise. This study answers to the following research question: How do international student teachers conceptualize cultural diversity and intercultural competences as part of their professional expertise.

\section{Intercultural education as a transversal theme in Finnish basic education}

In addition to teaching subject content, teachers should ensure that pupils practice a variety of skills and mindsets that are needed in today's world. In the newly revised Finnish National Core Curriculum for Basic Education 2014, published by the Finnish National Board of Education (hence FNBE) and implemented in 2016, the basic values of all teaching and learning activities entail to support pupils' "cultural competence based on respect for human rights, skills in appreciative interaction and means for expressing oneself and one's views" (FNBE, 2016 ${ }^{1}$, pp. 22-23). Although the curriculum does not use the concept of 'interculturality' or directly refer to intercultural competences, it uses the concept of 'cultural competence' and includes aims about guiding students to "appreciate the traditions and customs of their own family and community as well as those of others" and to "have international experiences" (FNBE, 2016, p. 102). The cultural and linguistic plurality is particularly visible in the way the new curriculum states that "education supports the pupils in building their personal cultural identity and their growth into active actors in their own culture and community" as well as support the pupils' "interest in other cultures" (FNBE, 2016, p. 16). These aims demonstrate that the curriculum covers many of the same content areas that are generally attached to intercultural competences. It remains unclear, however, what or how various traditions and experiences of internationality should be present in everyday learning processes.

Regarding intercultural education, one of the most notable differences between the new Finnish national core curriculum and the old curriculum from 2004 is the way the old document separated certain "cultural and language groups" (FNBE, 2004, p. 31) as groups that needed extra support in their identity construction and affiliation with the Finnish society. These groups included the Sami and Roma pupils, sign-language users, and immigrant pupils (FNBE, 2004, pp. 31-34). In relation to all of these groups, the curriculum highlighted that education should provide opportunities for the pupils of these groups to express and reinforce their minority identity, native language, and culture at school. Furthermore, in relation to immigrant pupils (which referred to both first and second generation immigrants), the curriculum explicitly pointed out that instruction "must support the pupils' growth into active and balanced membership of both the Finnish linguistic and cultural community and the pupils' own linguistic and cultural community" (FNBE, 2004, p. 34). This division

\footnotetext{
${ }^{1}$ The Finnish-language version of the Finnish National Core Curriculum for Basic Education 2014 was published in 2014, but the English-language version was not published until 2016.
} 
between the Finnish community and the pupils' "own linguistic and cultural community" thus suggested that identities, such as "Finnishness" or a "minority identity", are entities that can exist side-by-side, but that the multitude of affiliations concern only those pupils who have immigrant families. It also discussed all immigrant pupils as a single group and implied that all immigrant pupils need extra support for their identity construction. Contrary to this, the new curriculum does not make this type of division of cultural affiliations and identities between Finnish-born and non-Finnish born pupils but, instead, cultural and linguistic plurality is seen as a starting point for all pupils. It is important to note that although Finland has often been considered a monocultural country, it has for centuries had people of different home languages (including the Sami and Roma), numerous groups of minority religions, and different social classes (Holm \& Zilliacus, 2009). However the arrival of immigrants has brought in new dimensions of diversity (Holm \& Londen, 2010).

As a change from the previous document, the new curriculum is more in agreement with the international literature (e.g. Bradatan, Popan, \& Melton, 2010; Malazonia et al. 2017; Sobre, 2017) that has pointed out that people view the role and importance of cultural traditions and habits individually. In this critical understanding of multiculturalism, there are no permanent causalities between a person's cultural sense of herself and her actions (Dervin, 2011). Following this, education should give the pupils means and opportunities to think about their various social affiliations and the significance of these for their own identity (Sobre, 2017). Therefore, teachers should be cautious about not creating stereotypical images that would solidify social groups, such as nations, cultures, or religions in a too simplistic way but to recognize that there exists diversity within and between all groups (Dervin et al., 2012). ,

\section{Developing intercultural awareness through reflection}

Reflection refers to a conscious way of analyzing one's thinking and doing and it is an important tool that teachers in many different countries are trained to use in order to become aware of their own preconceptions, assumptions, skills, and knowledge (Schön, 1987). Indeed, reflexivity has become one of the most central issues of teacher education during the last few decades (e.g. Husu, Toom, \& Patrikainen, 2008). Reflection is tightly connected to lesson planning but, instead of focusing only on the immediate ways of acting, it is also essential for student teachers to be guided to reflect on the larger philosophical and educational aims that direct their teaching (e.g. Husu, Toom, \& Patrikainen, 2008). As Andreotti (2014) has indicated, teachers' ability to reflect on their thinking and actions is vital not only for improving practices for the now, but also for revealing and deconstructing the ways in which certain mindsets and power relations are maintained both explicitly and implicitly through education. Therefore, reflection should be a journey into one's ways of thinking and into the collective referents behind those ways of thinking and acting (e.g. Andreotti, 2014; Husu, Toom, \& Patrikainen, 2008; Schön, 1987). Reflection has also been recommended as an influential tool in studies about intercultural dialogue as one needs to have an understanding of oneself in order to have a respectful dialogical relationship with others (Abu-Nimer, 2001). Reflection is particularly useful for developing intercultural competences that consist of a variety of skills and knowledge that are difficult to detect and assess by another person but oneself (Dervin \& Hahl, 2015). Previous studies on teachers' intercultural competences have explored these competences from various viewpoints and special attention has been given, for example, to language and communication skills and to attitudes towards habits, beliefs, and traditions of 'the other' (e.g. Bastos \& Araújo e Sá, 2015; Dimitrov \& Haque, 2016; Günay, 2016).

In order to approach the question of intercultural competences from a viewpoint that is not strictly subject-specific but applicable to all subject teachers, we use and further develop a model of three dimensions of intercultural awareness as suggested by Andrade and Pinho (2003, as in Bastos \& Araújo e Sá, 2015, p. 133). These are the (1) social and political dimension, (2) the personal 
dimension, and (3) the pedagogic or methodological dimension (Andrade \& Pinho, 2003). All of these levels are present and intertwined in educational practices and, therefore, they are essential to be considered in teacher education. Although the model was originally developed for language learning, we use a slightly modified version that is also applicable for teachers of other subjects, such as Mathematics and Chemistry.

Following the ideas presented by Andrade and Pinho (2003) about the respectful encountering of others, Bastos and Araújo e Sá (2015) depict the first dimension titled social and political dimension as relating "to understanding the educational role that the language curriculum may play in the construction of societies equipped to deal with diversity" (p. 133). In this study, we further expand the social and political dimension to cover the ways in which the notions of culture and cultural diversities are depicted and transmitted through educational practices both explicitly and implicitly in various subjects (see also Malazonia et al., 2017). This includes the curriculum as well as the teachers' approaches to discussing diversities. The social and political dimension is central as culture is often attached to nations as being identical to a country that is monolingual and homogeneous (Risager, 2007). Piller (2011, pp. 61-62) has argued that in schools "children are socialised into a national identity" either through hidden or official curricula. This type of a nationalist approach suggests that there exists one culture within one country and one language. In reality, there are few countries where the people, for example, speak only one language. Nevertheless, in particular foreign language education has traditionally included teaching about 'cultural practices' or characteristics of speakers of a certain language or citizens of a certain nation. Recently, scholars have also remarked that these kinds of generalizations increase the risk of stereotyping and give a distorted and one-sided picture of a culture and people in a particular country (e.g. Dervin, 2011). As an alternative, scholars have underlined the fact that cultures are not static but fluid and constantly evolving entities (e.g. Bradatan, Popan, \& Melton, 2010). This understanding is also visible in the Finnish National Core Curriculum (FNBE, 2016) but how it is implemented in practice is not known.

The second dimension titled the personal dimension refers to "the unique and individual character of plurilingual and intercultural competences, seen as a result of the life trajectories of individuals and their professional and linguistic ideologies" (Bastos \& Araújo e Sá, 2015, p. 133; see also Andrade \& Pinho, 2003). The personal dimension thus highlights teachers' personal experiences and recognizes that teachers' professional identity is not created in isolation from the personal identity (Andrade \& Pinho, 2003; Zembylas \& Papamichael, 2017). The ability to reflect on one's own experiences, worldviews, and other background features is seen essential for starting a dialogue with others as one must first be knowledgeable of oneself in order to encounter others (Abu-Nimer, 2001; Dimitrov \& Haque, 2016). In this study, we apply the personal dimension to refer to the ways in which teachers are able to recognize the impact that their personal experiences and encounters with different cultural traditions have on their views and definitions of culture.

The third dimension, titled the pedagogic dimension, refers to the ways professional knowledge is put into practice when planning teaching and learning activities (Andrade \& Pinho, 2003; Bastos and Araújo e Sá, 2015, p. 133). In this study, we use the pedagogic dimension to refer both to teachers' ability to make conscious choices regarding the ways they bring forward questions of culture and cultural diversity (e.g. Malazonia et al. 2017), as well as to the ways they use themselves as examples of cultural diversity to their pupils.

\section{Participants, data, and methods}

In order to investigate future subject teacher's conceptualizations of cultural diversity and intercultural competences as part of their professional expertise, we collected data in reflective group discussions from student teachers who studied in an international teacher education program in Finland. The students taking part in this English-medium teacher education program originated 
from different countries in the world, and they had relocated to Finland either permanently or temporarily. The focus of this small case study (Cohen, Manion, \& Morrison, 2007) was set on the international program because one of the objectives of this study was to investigate if and if yes, how the heterogeneity of the students' backgrounds and their various affiliations with the Finnish society would show in the participants' views about cultural questions. The participants included nine student teachers who had backgrounds from North America, Europe (including Finland), Asia, and Africa, and of whom many had lived in a number of different countries besides their birth country and now Finland. The subjects they represented were English, French, Mathematics, Physics, and Chemistry. Both language and science students were included in this study as it was assumed that the approaches to interculturality would differ between the different students because of the different natures of the disciplines.

The data were collected in three semi-structured focus group discussions based on the teaching subject, i.e. one group had three science students and two groups had three language students each. The focus group was incorporated as an option for a reflection meeting that belonged to a reflection course that the students took with one of the authors. During the teacher education year, the students had previously taken a 2-credit lecture course on multicultural education. The key themes that the participants were asked to discuss in the focus group related to their professional identity and teaching in the globalized world. The students were asked to allow each participant to share their views equally and compare their understanding and perspectives, but they were told they did not need to agree on the issues. In order to interfere with the discussion as little as possible, after giving the instructions the participants were left to discuss without a researcher present (Marková, Linell, Grossen, \& Salazar, 2007). On the one hand, this allowed the participants to concentrate on the issues that they felt the most pressing or relevant. On the other hand, having no researcher facilitate the discussion resulted in somewhat different focus points although the participants followed the same discussion questions. Each focus group lasted about 1 hour 30 minutes.

The data were analysed with the help of a two-phased content analysis (Cohen, Manion, \& Morrison, 2007). We conducted first an inductive reading of the transcribed data and then categorized the data into key themes that we derived from the focus group discussions as central for the student teachers' professional expertise as science and language teachers. After the first round, we continued with a second round of theory-driven analysis. We categorized the key themes according to the (a) social and political, (b) personal, and (c) pedagogic dimensions of intercultural awareness, as suggested by Andrade and Pinho (2003, as in Bastos \& Araújo e Sá, 2015, p. 133), to investigate if and how the different types of experiences and competences the student teachers identified were related to different areas of teacher professionalism. During this second phase, we also re-grouped the themes we had identified in the first phase according to their types in order to identify similarities and controversies within and between each of the three key dimensions (Cohen, Manion, \& Morrison, 2007). An example of the two-phased analysis procedure is illustrated in Figure 1 below. 


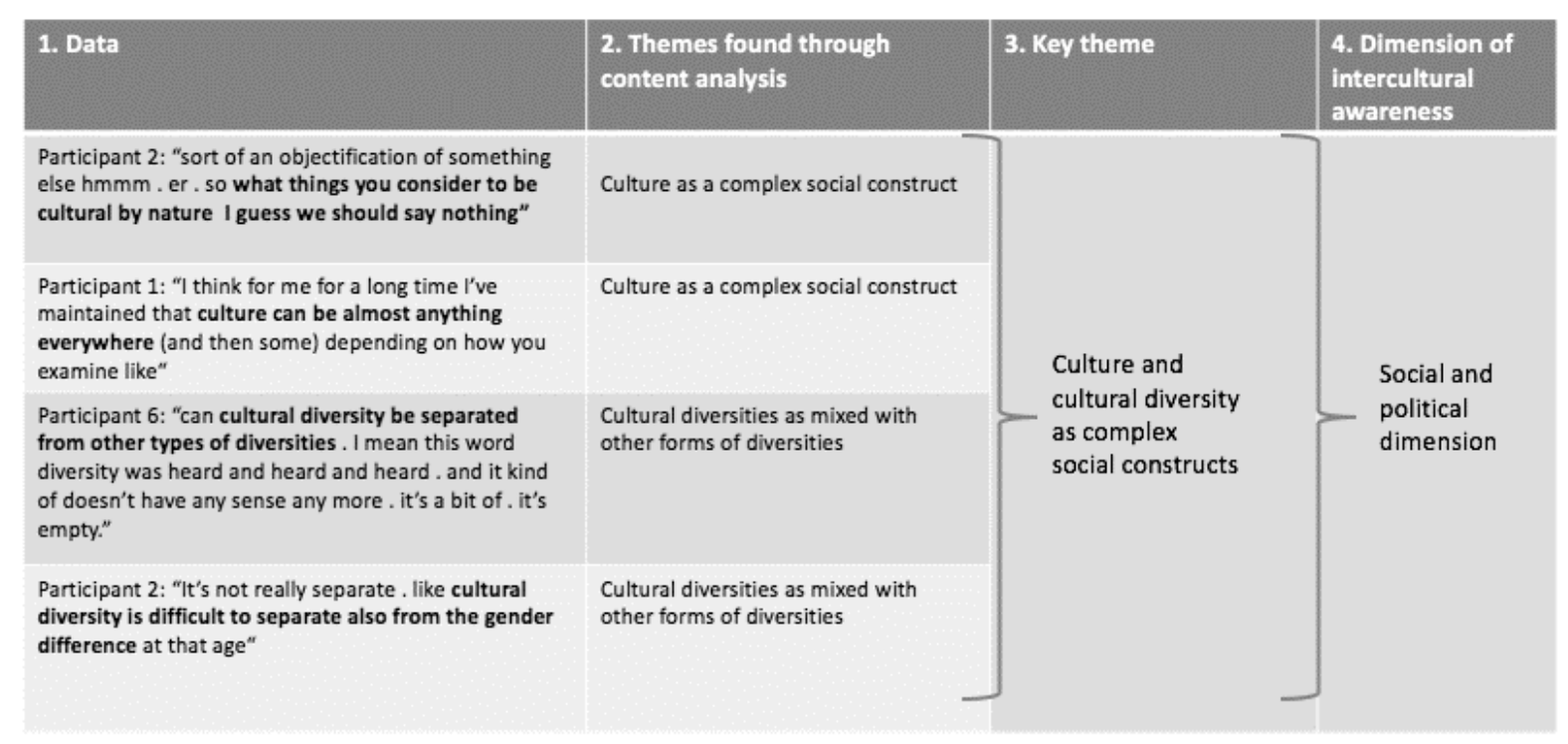

Figure 1: An example of the two-phased analysis procedure.

The data were first categorized into themes identified inductively from the data (first and second column from the left) and then grouped into key themes (third column) that were grouped according to their dimension. In the example, the extracts highlight discussions on the definition of culture and cultural diversity. The key theme is specified as "Culture and cultural diversity as complex social constructs" and it is identified to belong to the "Social and political dimension" of intercultural awareness, as the ways culture is defined have implicit and explicit consequences to the ways ideas and attitudes about diversity are depicted and transmitted through education (Malazonia et al., 2017). The analysis resulted into several sub-themes and dimensions but, in this study, we will focus on the themes that were the most related with the social and political, personal, and pedagogical dimensions of intercultural awareness in teachers' professionalism. The findings are presented in the following section and we will provide extracts of data to illuminate the findings.

\section{Findings: Student teachers' reflections about cultural diversity}

The student teachers (from here referred to as students) were prompted to discuss issues related to culture and cultural diversity and their understanding of these concepts. We will first discuss the findings in relation to the social and political dimension and then move on to the personal and pedagogic dimensions.

\section{Social and political dimension}

The social and political dimension includes two key themes that are the 'culture and cultural diversity as complex social constructs', and the 'implicit and explicit depiction of cultural diversity in one's own teaching'. The reflections the students had about culture and the ways in which they felt cultural issues were expressed in teaching showed that these questions were relevant for all of the participants regardless of their teaching subject.

\section{Culture and cultural diversity as complex social constructs}

One of the key themes emerging from the focus group data was the students' difficulty and hesitation in providing a clear definition of 'culture'. Even though the students started to define the concept through closely related and 'traditional' attributes, such as ethnicity and language, they were cautious and critical in relation to their suitability. Extracts 1, 2 and 3 illuminate the students' hesitations of the notion of culture: 


\section{Extract 1:}

Erik $^{2}$ : I think for me for a long time I've maintained that culture can be almost anything everywhere (and then some) depending on how you examine [--]

Ella: Yeah I mean I think that my first reaction to that culture theme was of course influenced by some of the readings that we had to do but uh. I don't think culture corresponds to ethnicity or uh . or language or . I mean it does to some degree but that's only part of the story

(Focus group 1)

\section{Extract 2:}

Bill: I'm not sure if that's something . but even I don't understand that word cultural

Leah: Exactly . I think . cultural by nature. what does it mean

Jane: For me this term . I never had any relation to it until I travelled . and people answered some questions that this is our culture. I never knew what my culture was . and I never felt that I have a culture

(Focus group 3)

These discussions in Extract 1 and 2 reflect the critical understanding of multiculturalism where culture is seen to consist of multiple dimensions (e.g. Dervin, 2011; Sobre, 2017). According to the focus group participants, being aware of the different viewpoints makes it difficult to define what kinds of issues can be considered cultural by nature, or what kinds of aspects can be described with the concept of cultural diversity. Moreover, the students in all focus groups were critical about generalizations that are made based on cultural differences and about the visibility of cultural issues. In Extract 3, the students discuss the close connections culture has with other forms of identities, such as nationalities, gender, and languages and, as Ella points out, these differences may also be age-related.

\section{Extract 3:}

Ella: It's not really separate . like cultural diversity is difficult to separate also from the gender difference at that age

Erik: I think it's very difficult to think of these things separately . there's fluidity in all things when you look at diversities like for example so yeah

(Focus group 1)

The students in all of the focus groups discussed the fluidity that exists within the different types of social identities, including cultural, that is highlighted in Extract 3 by Erik. These viewpoints in Extracts 1, 2, and 3 represent many of the ideas that are also discussed in international studies about the complexity and multiplicity of social groups in which people have memberships (e.g. Bradatan, Popan, \& Melton, 2010). The viewpoints also reflect the change that has happened in international literature regarding the concept of culture from a static entity to a constantly changing and evolving phenomenon (e.g. Dervin, 2011; Malazonia et al., 2017). Extract 4 from a conversation among Erik, Matt, and Ella reveals that the students recognize a change in the way culture has been referred to in the past and how it is used today. The students find the concept of culture problematic as, on the one hand, its meaning is vague and people understand it in different ways. On the other hand, people use it increasingly in multiple contexts.

\footnotetext{
${ }^{2}$ These names are pseudonyms. The transcription is broad. Extracts have be cleaned for easier reading. A short pause of any length is noted with a period (.). Cut-out speech is noted by [--].
} 


\section{Extract 4:}

Erik: So I think it's [culture] quite a problematic term actually I think most people wouldn't even realize that it's a problem because it's sort of like exactly the category thing and everything kind of starts becoming a culture [--] at the same time it's very multifaceted but also then when everything is culture how do we understand it really .

Matt: And who decides what defines culture

Ella: Yeah who decides . I think nowadays people tend to use it to describe something they don't understand . it's different from the way they do things

(Focus group 1)

In addition to the changes in concepts and definitions, the students also pondered critically on the meaningfulness of teaching and learning about cultural differences. In particular, the students pointed out the importance of teaching the children mindsets that allow them to live together with others in the global world. In Extract 5, Lily shows how she sees the teacher's responsibilities to extend beyond the discussions of diversity of different groups and, instead, focus on the personalities of people within these different groups.

\section{Extract 5:}

Lily: I think one of the biggest responsibilities . we have is also to teach how to live together . live together in the classroom . and it's not necessarily between nationalities or backgrounds or languages or stuff like that . but also personalities

(Focus group 2)

Although the students were unable to define culture in explicit terms, the extracts above exemplify that they were cognizant of the importance of being aware of cultural issues as part of teachers' professionalism. However, as evidenced in other extracts (e.g. Jack in Extract 9, and Bill in Extract $10)$, stereotypical images or generalizations were still present in the students' discourse when discussing other aspects in the focus group.

\section{Implicit and explicit depiction of cultural diversity in one's own teaching}

The students defined culture and cultural differences in various ways and these had several implications to their considerations of how subject teachers should take into account cultural issues in their own teaching. Even though the students found it difficult to provide an all-encompassing view of culture, both language students (Erik, Matti, and Ella; Jack, Lily, and Maya) as well as the science students (Leah, Jane, and Bill) attached the idea of culture primarily to the teaching of language, and regarded linguistic skills as a means to gain access to different cultures. Extracts 6 and 7 below show that this link with the teaching subject was noted by both language and science students.

\section{Extract 6:}

Jack: So for example when [--] you're teaching French that you teach them about these different countries that speak these different languages

Lily: [--] Are there topics that are not only linguistically related or language related . you can learn stuff in French and that's actually the purpose of the language because it's communication and access to culture

Jack: So actually learning something in the language itself is cultural activity 


\section{Extract 7:}

Leah: [--] When you teach a language . you have to bring the culture in the teaching . because [--] you don't learn a language separated from the culture . so then this topics are much more present than when teaching science . that maybe for us are not so relevant

(Focus group 3, science)

As an example of the science group's discussions, Extract 7 above reveals that the science students considered cultural issues as "not so relevant" when teaching science. However, later on, in another part of the discussion (Extract 8), Leah (a science student) contradicts this idea by indicating that it is important that different representations of people are given voice and presence within science lessons. In Extract 8 below, Leah describes how she finds it important that pupils are given examples of scientists who are not "white old men".

Extract 8:

Leah: In science when I think about chemistry or biology . usually the image that you have about scientists are male . white . old men [--] so I think it's important that while teaching chemistry [--] [to point] out that there are also other scientists or researchers . not only always old white men

Jane: Also different nationalities

Leah: [--] One example would be that the students do a research on scientists that are women [--] it can be colour . men of colour . women of colour

(Focus group 3)

To summarize the findings in this dimension, the students were inclined to avoid clear-cut definitions of culture and, instead, they elaborated on the complex nature of the topic. In addition to highlighting the connections between languages and certain countries, the students indicated that one language can be used in different countries and that the act of learning a language is "cultural activity" in itself (Extract 6). The science students, who at first were inclined to view cultural diversity as absent from their teaching content, specified the importance of having representatives of different genders, nationalities, and age groups incorporated in their teaching (Extract 8). The viewpoints about the importance of having representations of different types of people in the lessons thus indicate that questions of cultural diversity are not easily separated from other types of diversity but they are still important topics to be considered in the teaching of both languages and sciences (see also Malazonia et al., 2017).

\section{Personal dimension}

As suggested by Andrade and Pinho (2003), a teacher's professional identity is not separate from the personal experiences and identity of the individual but these aspects shape the teacher's intercultural competences. In this section, we discuss the findings in relation to the personal dimension and the students' 'personal experiences as a frame of reference for cultural diversity'.

\section{Personal experiences as a frame of reference for cultural diversity}

Even though the students were conscious of the different meanings, interpretations, and power relations related to the notion of culture, in many parts of the discussions the participants themselves talked about cultural differences and stereotypes as self-evident or natural. For example, in Extract 9 Jack describes how he has changed during his stay in Finland and now finds the shopping culture in English-speaking countries stressful. Through these comparisons, the stereotypical images of a talkative American and a silent Finn are strongly present in Jack's speech. Jack might be unaware of using stereotypes, or he might think that the use of these stereotypes is acceptable as he states that he does not promote one over the other ("I wasn't saying that this is better this is worse"). 


\section{Extract 9:}

Jack: I was asking them like who here has been to America English-speaking countries . (--) I was saying that was it weird for you . were they talking too much like compared to Finland . (--) I wasn't saying that this is better this is worse. I was telling them the opposite that I've become very Finnish and when I go back to America I'm very stressed out when American customer service talk to me I'm like give me a break I just wanna be quiet . I told them I've changed as well

(Focus group 2)

The images of silent Finns were also reproduced in comments by Bill who pointed out that "the way you treat people is cultural . you know . like Finns do not like small talks . it's their culture". In Extract 10 , Bill continued the comparison between traditions by explaining how in his home country the normal process of greeting another person can take several minutes. These extracts 9 and 10 thus show that the students sometimes viewed the idea of culture strongly through their own experiences. For example, in Extract 10, Bill describes the way of life in his tribe in Africa and considers the customs as cultural norms that must be and are adhered to. For another muchtravelled student, Jane, those 'rules' seems like something to be challenged and not necessarily followed.

\section{Extract 10:}

Bill: For me I think [--] first of all people (are clear) that life can be very cultural . because I come from a tribe in Africa that respect is very very very important. from the way you talk. if I want to speak to . there's different word that we use that is in my age group and somebody that is outside my age group

Jane: Is that something that you have learned as something typical for your culture

Bill: Yeah you learn that as a kid

Jane: Is that how you learned that this way is how we do it . kind of

Bill: It's just norm [--] nobody tells you this is how you do . you know nobody teaches from the model [--] you just learn that okay if I'm talking to my mom or my dad

Jane: Aren't there people who question it or who refuses to do it

Bill: Nobody

Jane: Because I question those

(Focus group 3)

These various ways of depicting cultural diversity show that there are many interpretations about the role and relationship 'culture' has in a person's life. The students were also confronted with the question of whether there are some national, religious, or other traditions that one finds hard to relate to as a teacher. Many of the students considered their experiences from different places and being international helpful when encountering diversity. Leah (Extract 11) felt particularly confident that her experiences of living in a country that differed notably from her home country have given her more knowledge about different traditions that she could use to also help children who have immigrated to Finland from other countries. In Extract 11, Leah explains how her experiences from multicultural environments help her in understanding "different religions and different cultures", and how the context of Thailand, where she lived before, was notably different from Finland and from her home country in Southern Europe.

\section{Extract 11:}

Leah: [--] If this question is related to Finland then [--] I don't find too hard to relate to as a teacher in Finland because for me . the Finnish culture is like my second culture. somehow . but if I compare to for example Thailand where I lived before then I would as a teacher I had to adjust a lot to the their traditions . with Buddhism or Thai traditions that they have every day.

Jane: When you teach here and suddenly you have a new kid from Somalia and one from Thailand and one from Ecuador . do you think you would have some problems . possibly 
Bill: No no

Leah: No

Jane: Could there be any problems . how can you be so sure?

Leah: For me my previous experience living in different countries and being in a multicultural environment . it really helps to . to approach all these things . and also the knowledge that you have about different religions and different cultures helps you to understand these things

(Focus group 3)

In the first section Social and political dimension, the findings show that the students mostly shared the theoretical idea of culture as a complex and fluid concept. However, the discussions the students had regarding their personal experiences of cultural encounters and working in multicultural environments imply that, in relation to their personal lives, they discussed culture in more fixed but yet dissimilar ways. The way Erik, Jack, Bill, and Leah brought forward national and cultural stereotypes is very different from the way Jane questioned these types of cultural norms. Therefore, the question of how the teachers' personal experiences of culture may influence their teaching is not as straightforward as one might assume based on the theoretical discussion about the concept.

While Bill and Leah seem to be confident about their ability to understand the difficulty a child may have when immigrating to new cultural surroundings, Jane does not show this type of certainty (Extract 11). The way these experiences may emerge in practical teaching and learning situations are discussed next.

\section{Pedagogic dimension}

We use the pedagogic dimension to both highlight the ways the students present themselves as embodiments of culture and discuss questions of culture and cultural diversity in their teaching. We have categorized the findings in this section to 'teacher as an example of cultural diversity' and 'stereotypical depictions of cultures as difference'.

\section{Teacher as an example of cultural diversity}

In many of the focus group discussions (e.g. Extract 13), the students mentioned their plans to include cultural aspects in their teaching. Some wanted, for example, to share experiences of their travels and stays in different countries around the world. During teaching practices, the students had noticed that pupils were often interested in hearing of the students' backgrounds. Some students felt that this interest could be used as a conversation starter in the classroom, or as a bridge to activities that will allow the pupils to work on their conceptions of diversity. Although it was more common in the focus group discussions to emphasize how the international students were multicultural examples for pupils, in Extract 12, Maya reminds the others how a Finnish teacher would also be a cultural example - as an "embodiment of the different cultures in Finland".

Extract 12:

Maya: [--] As a teacher we carry that cultural identity of the different places we come from even if you're a Finnish teacher you're still an embodiment of you know of the different cultures in Finland . and it plays out in how you communicate to the different students

(Focus group 2)

In Extract 12, it is noteworthy that Maya talks of "the different cultures in Finland" in the plural. She thus brings forth the understanding that Finland is and has been pluralistic and multicultural. Compared to many other countries, Finland was visibly more homogenous until the arrival of immigrants in the 1990's. However, although Finland has not traditionally had such diversity of perceivable cultural differences of, for example, people of different skin color or religious headdress, there are other dimensions of diversity that have existed in Finland for much longer and that are important to acknowledge (Holm \& Zilliacus, 2009). 


\section{Stereotypical depictions of cultures as difference}

As analysed above, in some parts of the focus group discussions the students demonstrated a critical understanding of culture. However, there were other parts of the discussions that again revealed the complexity of the notion of culture and the students' stereotypical depictions of cultures. Extract 13 below serves as one example of many of the students' tendency to fall back on the traditional and more solid understanding of different cultures that they attach to different countries. In Extract 13, the students think of ways to incorporate international experiences in their teaching and explain how they will tell their pupils stories of their travels. However, as Leah and Bill talk about the immigrant pupils in the class and describe how they can "understand their cultures" and "know how to relate to them" because of their travels, the students make individuals from particular countries (or even continents) as representatives of a whole nation. Teachers need to exercise caution with such impressions in order not to neglect the individuality of the pupil (see Sobre, 2017).

\section{Extract 13:}

Bill: I think I'm gonna to tell them some stories of how I've traveled

Jane: Yeah me too

Bill: And try to bring that into the classroom . because most of those kids have travelled you know . in the international schools

Leah: Yeah I think this is the same thing as we said before like having lived in many countries it makes me understand the cultures and then I can understand their cultures and their habits and then give examples [--]

Bill: I think it also helps you to relate with the students. if they. if all of them are not from there and because you're an international person and you've known a little bit of Asian culture or Indian culture or African, South American [--] and you have them in the classroom . and you can you know how to relate to them . or if there is a Chinese guy

(Focus group 3)

Below in Extract 14, Ella brings up how cultural issues are inherently tied to foreign language learning. Interestingly, she does not share how she would teach about cultural issues, but instead she sort of shifts the responsibility and explains how other people "using culture in the old-fashioned way" would talk about the French "eating cheese and drinking wine".

\section{Extract 14:}

Ella: [--] Also if you're teaching in a distinct foreign language you would take cultural issues into account having to do with that culture of the place where people speak that language . like French is my subject so [--]if you were using culture in the old-fashioned way of you know people speak a particular language and live in a place and do things a certain way and eat cheese and drink wine and whatever people might think French people do

(Focus group 1)

Although a stereotype of a French eating cheese and drinking wine may correctly represent the habits of a French person, a question should be raised how or if this type of an image is useful or important when educating pupils to live in a global world. If the discussion of cultural diversities centers on stereotypical images and common customs, and habits of people of a particular country, it is difficult or impossible to see people as unique individuals who have many other characteristics and attributes that define them more than a nationality (Dervin, 2011).Therefore, it is necessary that teachers are equipped with critical skills to consider multiculturalism in such ways that enhance understanding and help alleviate the use of stereotypical images. 


\section{Discussion}

The ways in which cultures and identities are perceived and how representations of these are transmitted in education are central questions for all educators. The research question of this study was "How do international student teachers conceptualize cultural diversity and intercultural competences as part of their professional expertise." This study used reflection as a method because reflection is considered a particularly important and useful tool for developing teachers' awareness about the ways they organize pedagogical practices (e.g. Andreotti, 2014; Husu, Toom, \& Patrikainen, 2008). In order to answer to the research question, we analyzed student teachers' reflections about culture by applying a modified version of the three-dimensional model suggested by Andrade and Pinho (2003, see also Bastos \& Araújo e Sá, 2015). The main findings show that the three dimensions of the (a) social and political, (b) personal, and (c) pedagogic viewpoints are all closely linked and can be intertwined in the everyday thinking of the student teachers, but they may also be reflected by the student teachers in contradictive and shallow ways.

Regarding the social and political dimension (Andrade \& Pinho, 2003; Bastos \& Araújo e Sá, 2015) that, in this study, referred to the ways the students conceptualize the idea of culture, the findings indicate that the students were noticeably cautious in providing a definition for culture or cultural differences. The key themes of this dimension were -'Culture and cultural diversity as complex social constructs' and 'Implicit and explicit depiction of cultural diversity in one's own teaching' that showed that students expressed strong endeavors to see the fluidity of cultures and identities, both theirs and those of their pupils, and they wanted to refrain from forming too closed or fixed images about cultural difference. Corresponding with international literature about interculturality in education (Sobre, 2017; Hernández-Bravo, Cardona-Moltób, \& Hernández-Bravo, 2017), the research participants regarded as a key competence for teachers to refrain from categorizing the pupils too strictly into cultural groups as well as to bring forward representations of all kinds of different people. These findings support the ideas represented vastly in international literature about culture as a constantly changing and evolving phenomenon and about the importance of teacher awareness of these complexities (e.g. Dervin \& Hahl, 2015; Hahl \& Löfström, 2016; Malazonia et al., 2017).

Although the students highlighted the importance of approaching culture as a fluid entity, the findings related to the personal dimension of intercultural awareness (Andrade \& Pinho, 2003; Bastos \& Araújo e Sá, 2015) indicate that the student teachers struggled to maintain the same approach when talking about their personal experiences. The findings in this dimension's one key theme called 'Personal experiences as a frame of reference for cultural diversity' support the suggestions made previously by Andrade and Pinho (2003) and Bastos and Araújo e Sá (2015) about the importance of taking into account the teachers' personal experiences in developing intercultural competences. The student teachers simultaneously wanted to avoid making clear-cut definitions of culture but still relied on very strong stereotypes regarding French, Finnish, American, or African people. Such contradictive findings call for the importance of educators to reflect on cultural questions in relation to their own background and experiences, so that they are able to distinguish their own preconceptions, prejudices, or set ideas (e.g. Andreotti, 2014; Dervin \& Hahl, 2015).

In relation to the pedagogic dimension of intercultural awareness (Andrade \& Pinho, 2003; Bastos \& Araújo e Sá, 2015), the findings were divided into two themes that were 'Teacher as an example of cultural diversity' and 'Stereotypical depictions of cultures as difference'. These key themes indicate how the personal dimension of students' experiences was in many ways attached to how the students planned to express cultural diversity and to use their personal experiences as part of their teaching. In connection to the personal dimension, many of the students considered themselves as embodiments of culture and they had decided to integrate their own experiences of living and traveling abroad as part of their teaching. The examples given by the student teachers about 
different national and cultural traditions in other parts of the interview implied however, that despite of their shared understanding of culture in theory, they conceptualize their own experiences in different ways. It can thus be assumed that the student teachers will also carry out intercultural education in their teaching in various ways.

Overall the findings of this study support the international need for subject teachers to be conscious about the ways they discuss and present culture (Sobre, 2017; Zembylas \& Papamichael, 2017). One way to exemplify how culture can be manifested in teaching is through the three dimensions used in this study, each of which discusses different aspects of culture in teachers' professionalism. The different types of conflicts with the educational aims and practices raised in this study show that it is vital for teacher educators and student teachers themselves to pay attention to student teachers' understanding of the meaning of interculturality. It is important to learn of (student) teachers' ability to identify and describe the aims and means related to education that strive to support pupils' growth into open-minded, knowledgeable, and respectful individuals in the global world.

It is important to note that this was a small case study that was based on the student teachers' personal reflections. Thus, caution must be exercised regarding the generalization of the findings and future studies are needed in order to know how teachers actually act with their students. The findings of this study indicate, nonetheless, that it is important to challenge student teachers to think critically about their own backgrounds and views on multiculturalism, regardless of the extent of international experiences they have already gained.

The role of cultural and other identities is connected to an individual's conception of different values and worldviews, and in the increasingly diverse school environment such competences are all the more topical (e.g. Hernández-Bravo, Cardona-Moltób, \& Hernández-Bravo, 2017; Malazonia et al., 2017). In agreement with international literature (e.g. Yang \& Montgomery, 2013; Zembylas \& Papamichael, 2017), the findings of this study highlight the importance of teachers' abilities to recognize and verbalize their own viewpoints and prejudices regarding cultural issues in order to support the development of pupils' intercultural competences.

\section{Conclusion}

The core aims of the pedagogical approaches within the tradition of critical intercultural education are to take pupils' diverse backgrounds into account in teaching in such a way that it supports the pupils' engagement in the local community and global world (e.g. Davis, Phyak, \& Bui, 2012; Malazonia et al., 2017). However, internationally conducted studies show that teachers' knowledge about intercultural aspects is often insufficient to enhance their abilities in considering diversity in teaching (Malazonia et al., 2017).

The findings of this study support the need for educators to be able to critically reflect on their own viewpoints about culture and on the discrepancies that may exists between the theoretical, personal, and practical ways of discussing and implementing culture as part of education. Although stereotypes are not necessarily negative and they may represent issues that can be applicable to the majority of people sharing the same group affiliations, it is important that teachers do not use their individual experiences as frameworks to teach about whole cultural systems, or lead pupils to think in narrow and hegemonistic ways of culture. Instead, teachers should focus on finding ways how all people can live together and learn from each other in a dialogical way (e.g. Abu-Nimer, 2001; Sobre, 2017). 


\section{References}

Abu-Nimer, M. (2001). Conflict resolution, culture, and religion: Toward a training model of interreligious peacebuilding. Journal of Peace Research, (6)38, 685-704.

Andrade, A., \& Pinho, A. (2003). Former à l'intercompréhension: Qu'en pensent les futurs professeurs de langues? Lidil, 28, 173-184. URL: http://lidil.revues.org/1973

Andreotti, V. (2014). Critical literacy: Theories and practices in development education. Policy \& Practice: A Development Education Review, 14, 12-32.

Bastos, M., \& Araújo e Sá, H. (2015). Pathways to teacher education for intercultural communicative competence: Teachers' perceptions. The Language Learning Journal, 43(2), 131-147. DOI: 10.1080/09571736.2013.869940.

Bradatan, C., Popan, A., \& Melton, R. (2010). Transnationality as a fluid social identity. Social Identities, 16(2), 169-178.

Cohen, L., Manion, L., \& Morrison, K. (2007). Research Methods in Education. London, UK: Taylor \& Francis.

Davis, K., Phyak, P., \& Bui, T. N. (2012). Multicultural education as community engagement: Policies and planning in a transnational era. International Journal of Multicultural Education, 14(3), 125.

Dervin, F. (2011). A plea for change in research on intercultural discourses: A 'liquid' approach to the study of the acculturation of Chinese students. Journal of Multicultural Discourses, 6(1), 3752. DOI: $10.1080 / 17447143.2010 .532218$

Dervin, F. \& Hahl, K. (2015). Developing a portfolio of intercultural competences in teacher education: The case of a Finnish international programme. Scandinavian Journal of Educational Research 59(1). 95-109.

Dervin, F., Paatela-Nieminen, M., Kuoppala, K., \& Riitaoja, A.-L. (2012). Multicultural Education in Finland: Renewed Intercultural Competences to the Rescue? International Journal of Multicultural Education, 14(3), 1-13. DOI: 10.18251/ijme.v14i3.564

Dimitrov, N., \& Haque, A. (2016). Intercultural teaching competence: A multi-disciplinary model for instructor reflection. Intercultural education, 27(5), 437-456.

Günay, O. (2016). Teachers and the foundations of intercultural interaction. International Review of Education, (4)62, 407-421.

Finnish National Board of Education (FNBE). (2004). National Core Curriculum for Basic Education 2004: National core curriculum for basic education intended for pupils in compulsory education. Retrieved from http://www.oph.fi/english/curricula_and_qualifications/basic _education

Finnish National Board of Education (FNBE). (2016). Finnish National Core Curriculum for Basic Education 2014. Publications 2016: 5. Helsinki: FNBE.

Hahl, K., \& Löfström, E. (2016): Conceptualizing interculturality in multicultural teacher education, Journal of Multicultural Discourses, DOI: 10.1080/17447143.2015.1134544

Hernández-Bravo, J., Cardona-Moltó, C., \& Hernández-Bravo, J. (2017) Developing elementary school students' intercultural competence through teacher-led tutoring action plans on intercultural education. Intercultural Education, 28(1), 20-38, DOI: 10.1080/14675986.2017.1288985

Holm, G., \& Londen, M. (2010). The discourse on multicultural education in Finland: education for whom? Intercultural Education, 21(2), 107-120. DOI: 10.1080/14675981003696222

Husu, J., Toom, A., \& Patrikainen, S. (2008). Guided reflection as a means to demonstrate and develop student teachers' reflective competences. Reflective Practice: International and Multidisciplinary Perspectives, 9(1), 37-51. DOI: 10.1080/14623940701816642

Malazonia, D., Maglakelidze, S., Chiabrishvili, N., \& Chiabrishvili, M. (2017). Education in multicultural environment - Teaching/learning support activities (on the example of Georgia). Intercultural Education, DOI: 10.1080/14675986.2017.1297072 
Marková, I., Linell, P., Grossen, M., \& Salazar, O. (2007). Dialogue in focus groups: Exploring socially shared knowledge. London, UK: Equinox Publishing.

Piller, I. (2011). Intercultural Communication: A Critical Introduction. Edinburgh, UK: Edinburgh University Press.

Risager, K. (2007). Language and Culture Pedagogy: From a National to a Transnational Paradigm. Languages for Intercultural Communication and Education. Clevedon, UK: Multilingual Matters.

Schön, D. A. (1987). Educating the reflective practitioner. Washington, DC: American Educational Research Association.

Sobre, M. (2017). Developing the critical intercultural class space: Theoretical implications and pragmatic applications of critical intercultural communication pedagogy. Intercultural Education, 28(1), 39-59. DOI: 10.1080/14675986.2017.1288984

Yang, Y., \& Montgomery, D. (2013). Gaps or bridges in multicultural teacher education: A Q study of attitudes toward student diversity. Teaching and Teacher Education, 30, 27-37. DOI: 10.1016/j.tate.2012.10.003

Zembylas, M., \& Papamichael, E. (2017) Pedagogies of discomfort and empathy in multicultural teacher education. Intercultural Education, 28(1), 1-19, DOI:

10.1080/14675986.2017.1288448 